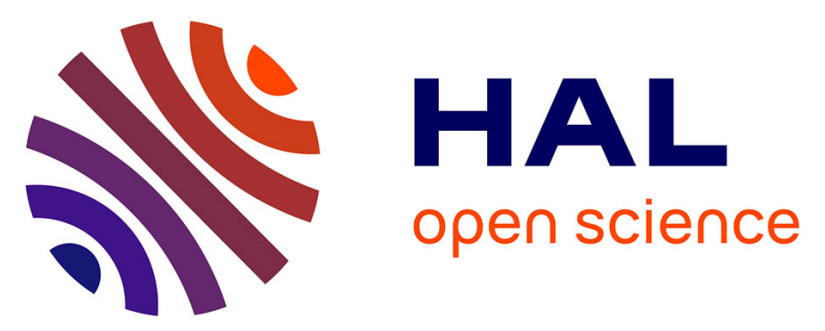

\title{
Physical Stability and Interfacial Properties of Oil in Water Emulsion Stabilized with Pea Protein and Fish Skin Gelatin
}

Mar Vall-Llosera, Flemming Jessen, Pauline Henriet, Rodolphe Marie, Mastaneh Jahromi, Jens J Sloth, Mohammad Amin Mohammadifar, Heidi Olander Petersen, Bo Munk Jørgensen, Federico Casanova

\section{To cite this version:}

Mar Vall-Llosera, Flemming Jessen, Pauline Henriet, Rodolphe Marie, Mastaneh Jahromi, et al.. Physical Stability and Interfacial Properties of Oil in Water Emulsion Stabilized with Pea Protein and Fish Skin Gelatin. Food Biophysics, 2020. hal-03008003

\section{HAL Id: hal-03008003 https://hal.inrae.fr/hal-03008003}

Submitted on 16 Nov 2020

HAL is a multi-disciplinary open access archive for the deposit and dissemination of scientific research documents, whether they are published or not. The documents may come from teaching and research institutions in France or abroad, or from public or private research centers.
L'archive ouverte pluridisciplinaire HAL, est destinée au dépôt et à la diffusion de documents scientifiques de niveau recherche, publiés ou non, émanant des établissements d'enseignement et de recherche français ou étrangers, des laboratoires publics ou privés.

\section{(ㅇ)(1) $\$$}

Distributed under a Creative Commons Attribution - NonCommercial - NoDerivatives 44.0 


\title{
Physical Stability and Interfacial Properties of Oil in Water Emulsion Stabilized with Pea Protein and Fish Skin Gelatin
}

\author{
Mar Vall-llosera ${ }^{1} \cdot$ Flemming Jessen ${ }^{1} \cdot$ Pauline Henriet $^{1,2} \cdot$ Rodolphe Marie $^{3} \cdot$ Mastaneh Jahromi $^{1} \cdot$ Jens J. Sloth $^{4}$. \\ Mohammad Amin Mohammadifar ${ }^{1} \cdot$ Heidi Olander Petersen ${ }^{1} \cdot$ Bo Munk Jørgensen ${ }^{1} \cdot$ Federico Casanova ${ }^{1}$
}

Received: 20 July 2020 / Accepted: 5 October 2020

(C) Springer Science+Business Media, LLC, part of Springer Nature 2020

\begin{abstract}
This study aimed to investigate the physical stability and interfacial properties of oil-in-water $(\mathrm{O} / \mathrm{W})$ emulsions stabilized with fish skin gelatin (FG) and pea protein (PP) at pH 3. Physico-chemical properties, elemental composition and SDS-PAGE of the proteins were determined in the first part of this work. Emulsions were prepared at different ratio FG: PP (100: 0-75: 25-50: 5025: 75-0: 100) by mechanical stirring followed by ultrasound treatment. Higher physical stability was observed in the presence of $\mathrm{FG}$ (ratio 100: 0), where the $\mathrm{O} / \mathrm{W}$ were stable $\sim 50 \mathrm{~h}$. An average hydrodynamic diameter $<1 \mu \mathrm{m}$ was found for all the emulsions except for the ratio $75: 25$, where it was $2.8 \mu \mathrm{m}$. The presence of the protein on the $\mathrm{O} / \mathrm{W}$ interface was explored by confocal laser scanning microscopy whereas the thermal properties of the protein ratios were analyzed by differential scanning calorimetry. The lower denaturation temperature was observed for ratio 50: 50, which was founded at $\sim 89^{\circ} \mathrm{C}$, whereas the denaturation temperatures for the others $\mathrm{O} / \mathrm{W}$ emulsions were in the range of 99 and $108^{\circ} \mathrm{C}$. A predominant viscous behavior was observed for all the ratios while a slight decrease of the surface tension was observed in the presence of PP. The equal mixing of FG with PP showed an increase in the emulsifying properties of PP forming a more stable emulsion with lower particle size.
\end{abstract}

Keywords Fish skin gelatin $\cdot$ Pea protein $\cdot \mathrm{O} / \mathrm{W}$ emulsion $\cdot$ Ultrasound treatment $\cdot$ Physical stability

\section{Introduction}

Emulsions are defined as a dispersion of two or more immiscible liquids in which one of the liquids is dispersed in the other as small droplets $(0.1-100 \mu \mathrm{m})$ [1]. In the food industry, we typically found oil-in-water $(\mathrm{O} / \mathrm{W})$ emulsions, for instance,

Electronic supplementary material The online version of this article (https://doi.org/10.1007/s11483-020-09655-7) contains supplementary material, which is available to authorized users.

Federico Casanova

feca@food.dtu.dk

1 Research Group for Food Production Engineering, National Food Institute, Technical University of Denmark, Søltofts Plads, 2800 Kongens Lyngby, Denmark

2 Agrocampus Ouest, UMR 1253, F-35042 Rennes, France

3 Department of Health Technology, Technical University of Denmark, Ørsted Plads, 2800 Kongens Lyngby, Denmark

4 Research Group for Nano-Bio Science, National Food Institute, Technical University of Denmark, Kemitorvet, 2800 Kongens Lyngby, Denmark butter, margarine and spreads, which consist of water droplets dispersed in an oil phase. Homogenization is the process to mix two immiscible liquids into one single phase [2]. In food manufacturing, the homogenization is usually performed by applying an intense mechanical agitation to a liquid mixture using a "homogenizer", such as high shear mixer, highpressure valve homogenizer, colloid mill, microfluidizer or ultrasonic homogenizer [3]. The ultrasound technique has been extensively explored to produce formulations containing oil in an aqueous media for food and pharmaceutical applications due to its safety and non-toxicity characteristics [4]. Low frequencies $(20-100 \mathrm{kHz})$ coupled with high intensity (10$1000 \mathrm{~W} \mathrm{~cm}^{-2}$ ) are generally employed for the alteration and modification of foods, either physically or chemically [5]. Particularly, high-intensity ultrasonic waves act on droplets disruption, mainly due to the cavitation phenomena, which is caused by rarefaction and condensation cycles of ultrasound waves [3]. The ultrasonic cavitation cause localized regions of intense hydrodynamic shear forces and a rise in the temperature at the site of bubble collapse [5]. Emulsions are formed in the presence of an emulsifier. As a result of having both hydrophobic and hydrophilic components emulsifiers can be 
integrated into the $\mathrm{O} / \mathrm{W}$ interface, lowering the interfacial tension [6]. Emulsifiers such as proteins are widely employed in food processing because of their ability to be adsorbed into oil-water interfaces and form interfacial films [7]. The most employed proteins in research and the food industry are whey protein isolate [8], casein [9] and bovine serum albumin [10]. However, over the past few years, a change has been observed in the consumption trends of animal origin products. Mainly because of ecological problems, animal welfare, allergies, restrictions due to ethical, religious and health reasons. Gelatin from fish sources is considered a side-stream product for the fishery industry, contrary to bovine meat, which is associated with the risk of bovine spongiform encephalopathy contamination, fish skin gelatin is not associated with the risk of being contaminated by BSE or viral infections [11]. In recent years, marine gelatin has shown promising results for being used as an alternative to bovine or pork gelatin [11]. Although the emulsifying abilities of fish gelatin have been studied, there is still a need for further research on the application of this ingredient in a colloidal system to achieve similar results than those using mammalian gelatins [12-14]. In parallel, there has been an up-coming trend to move toward a partial or complete replacement of proteins from animal sources with plant-based proteins, followed by an increase in the studies published on plant proteins. Liang et al. [15] investigated the emulsion stability formed by the mixing of pea, soy and whey protein. The authors' objectives were (i) to achieve excellent storage stability and (ii) to understand the effect of mix different protein ratios on the development of stable formulations with an improvement on the functional properties. Recently, Hinderink et al. [16] investigated the synergist effect of $\mathrm{O} / \mathrm{W}$ emulsions stabilized by a blend of pea protein isolate with whey protein isolate or with sodium caseinate. The authors show that the mixing of proteins can be used to produce emulsions with physical stability that is superior compared to emulsions prepared with the individual proteins. Further, pea proteins are becoming increasingly popular because of their technofunctional properties superior to soya as emulsifiers and foaming agents in basic and acid $\mathrm{pH}$ [17]. Pea protein on emulsions at pH 3 showed high stability [18]. Besides, pea proteins have lower allergenic potential compared to soy proteins. Pea proteins are composed with globular proteins $11 \mathrm{~S}$ legumin, $7 \mathrm{~S}$ vicilin and convicilin, of which vicilin has the highest emulsifying activity [19].

This study aims to investigate $(i)$ the physical stability of $\mathrm{O} / \mathrm{W}$ emulsions composed by different ratios of fish skin gelatin and pea protein and (ii) their possible synergistic effect in bulk and at the air-water interface. In the first part of the work we determined the physico-chemical and biochemical composition of the raw materials PP $(86 \% \mathrm{w} / \mathrm{w})$ and FG $(97 \% \mathrm{w} / \mathrm{w})$ : moisture, ash, protein content, mineral composition, hydrophobicity and protein patterns by SDS-PAGE. The physical stability of $\mathrm{O} / \mathrm{W}$ emulsions, as a function of time, were investigated with Turbiscan instrument, whereas their viscosity in bulk was analyzed by a rheometer. Thermal properties of proteins in powder, in slurry solution and $\mathrm{O} / \mathrm{W}$ emulsions were investigated by differential scanning calorimetry (DSC). Optical microscopy coupled with image analysis was employed to analyze the dispersion of the droplets whereas confocal scanning laser microscopy (CLSM) was chosen to investigate the presence of the protein on the $\mathrm{O} / \mathrm{W}$ interface. Interfacial properties at the $\mathrm{O} / \mathrm{W}$ interface was investigated by pendant drop analysis, in static and oscillating mode.

\section{Materials and Methods}

The two different proteins were employed: pea protein (PP) Nutralys F85F (Roquette Frères, Lestrem, France) and fish gelatin (FG) from cold fish water skin from Sigma (Sigma, St. Louis, MO, US). The disperse phase was fish oil with natural flavor from Lipromar (Cuxhaven, Germany). A buffer solution at $\mathrm{pH} 3$ was prepared by dissolving $9.9 \mathrm{~g}$ of sodium hydroxide into $250 \mathrm{ml}$ of Milli-Q water in a $500 \mathrm{ml}$ bottle following the addition of $21 \mathrm{~g}$ of citric acid and stirring until dissolution. Then $200 \mathrm{ml}$ of the solution were transferred into a $1 \mathrm{~L}$ glass bottle and the $\mathrm{pH}$ was adjusted at the value of 3 by using a $0.1 \mathrm{M}$ hydrochloric acid (37\%).

\section{Physico-Chemical Properties}

The moisture and ash content were analyzed according to the AOAC 930.15 and 942.05 [20]. The total nitrogen was determined by using the Dumas method and a conversion factor of 6.25 was used to determine the protein content [18].

\section{Hydrophobicity}

For the hydrophobicity analysis, 3 different concentrations were used: $0.5,0.05$ and $0.001 \%(w / w)$ of protein, dissolved in buffer ( $\mathrm{pH} 3$ ). The samples were prepared using $5 \mathrm{ml}$ of PP and FG solutions, and a blank using pH 3 buffer solution without the addition of proteins. A volume of $20 \mu \mathrm{l}$ of ANS (8-Anilino-1-naphthalenesulfonic acid) $8 \mathrm{mM}$ (Sigma, St. Louis, MO, US) was added in each preparation and kept in the dark for $10 \mathrm{~min}$. The samples were measured with a well plate using SPECTRAmax GEMINI (Molecular Devices, San Diego, CA, US) with a wavelength of $370 \mathrm{~nm}$ (excitation) and $470 \mathrm{~nm}$ (emission) [21].

\section{Electrophoretic Study or SDS-PAGE}

The SDS-PAGE analysis was performed by the method described by Leammli [22] using $12 \%$ acrylamide, slab gels ( $1.5 \mathrm{~mm}$ inside diameter). A quantity of $50 \mathrm{mg}$ of dry protein was added into $2 \mathrm{ml}$ of $1 \%$ sodium dodecyl sulfate (SDS) in 
the presence of $100 \mathrm{mM}$ dithiothretiol (DTT) and $60 \mathrm{mM}$ Tris $\mathrm{HCl}$ at $\mathrm{pH}$ 8.3. The mixture was shaken for $1 \mathrm{~h}$ at room temperature and then mixed with Polytron PT 1200, Kinematical during $30 \mathrm{~s}$. Afterward, it was boiled for $2 \mathrm{~min}$ and rested for $30 \mathrm{~min}$ at room temperature. Subsequently, the sample was homogenized and brought to boiling temperature for $2 \mathrm{~min}$. Then it was centrifuged at $20^{\circ} \mathrm{C}$ for $15 \mathrm{~min}$ at $20.000 \mathrm{~g}$. The supernatant was collected and diluted in a buffer with $125 \mathrm{mM}$ tris $\mathrm{HCl}$ at $\mathrm{pH}$ 6.8, 2.4\% SDS, $50 \mathrm{mM}$ DTT, $10 \%$ glycerol, $0.5 \mathrm{mM}$ EDTA and bromophenol blue. The gel was loaded with $10 \mu \mathrm{l}$ of sample aliquot, corresponding to $40 \mu \mathrm{g}$ of the dry sample. The voltage used during the electrophoresis was fixed at $100 \mathrm{~V}$ for $15 \mathrm{~min}$, followed by $150 \mathrm{~V}$ for $1 \mathrm{~h}$. The dye used to stain the gel was Coomassie Brilliant Blue, as described by Rabilloud and Charmont [23], with molecular weight marker (Mark12 ${ }^{\mathrm{TM}}$ from Novex, Thermo Fisher Scientific, Waltham, MA US).

\section{Determination of Elemental Composition}

Samples for elemental composition analysis were prepared by microwave-assisted digestion (Multiwave 3000, Anton Paar, Graz, Austria) with concentrated nitric acid (SPS Science, Paris, France) and diluted by milli-Q water (Millipore, Milford, MA, USA) prior to analysis with inductively coupled plasma mass spectrometry (Thermo iCAPq ICPMS, Thermo Electron, Thermo Fisher Scientific). For element quantification, an external calibration curve was used, adjusted to yttrium as an internal standard. The calibration standards were prepared with certified stock solutions (SPS Science). Method performance was evaluated using a certified reference material (DORM-4 fish protein, National Research Council of Canada, Ottawa, ON, Canada).

\section{Sample Preparation}

The total protein concentration was $1 \%$ (dry weight) in a buffer solution at $\mathrm{pH}$ 3. Different FG: PP ratios were investigated: 100:0 (A), 75:25 (B), 50:50 (C), 25:75 (D) and 0:100 (E).The different mixtures were prepared and placed under stirring overnight at room temperature $\left(20 \pm 1{ }^{\circ} \mathrm{C}\right)$. Sodium azide (Sigma, St. Louis, MO, US) $0.02 \%$ was added to avoid any microbiological contamination.

\section{Emulsion Preparation}

The O/W emulsions (1:99) were produced using the ultraturrax Yellow line DI25 (IKA, Staufen Germany) in three steps. The first step was at $8.000 \mathrm{rpm}$ for $5 \mathrm{~min}$, in which the oil was added at $1 \mathrm{ml} / \mathrm{min}$ during the first $2 \mathrm{~min}$, followed by mixing at the same speed for $3 \mathrm{~min}$. During the second step, the speed was fixed at $20.500 \mathrm{rpm}$ for $5 \mathrm{~min}$. In the last phase, the homogenized emulsion was submitted to ultrasound treatment (Branson, Danbury, CT, US) in a pulse mode for $10 \mathrm{~min}(10 \mathrm{~s} \mathrm{ON}$ and $10 \mathrm{~s} \mathrm{OFF})$ at $20 \mathrm{kHz}, 550 \mathrm{~W}$. The intensity of the treatment was determined for each emulsion using both equations [24]:

$P a=M \cdot C p \cdot\left(\frac{d T}{d t}\right)$

$I a=\frac{P a}{S a}$

where $P a$ is power (W), $M$ is the mass ( $\mathrm{g}), C p$ is the specific heat $\left(\mathrm{kJ} / \mathrm{g}{ }^{\circ} \mathrm{C}\right)$ and $d T$ and $d t$ are the differential of temperature and time respectively during the first $30 \mathrm{~s}$. Ia is the intensity of treatment which is equal to the power $(\mathrm{Pa})$ divided by surface area $(\mathrm{Sa})$ [24]. The intensity of treatment for the emulsions were found at $8.18 \mathrm{w} / \mathrm{cm}^{2}(\mathrm{~A}), 4.75 \mathrm{w} / \mathrm{cm}^{2}(\mathrm{~B}), 5.71 \mathrm{w} /$ $\mathrm{cm}^{2}(\mathrm{C}), 4.72 \mathrm{w} / \mathrm{cm}^{2}$ (D) and $7.99 \mathrm{w} / \mathrm{cm}^{2}(\mathrm{E})$, respectively.

\section{Turbiscan}

Turbiscan Tower (Formulaction, Toulouse, France) was used as a quantitative method to determine the stability of the emulsions. The principle behind this technique is the use of light $(850 \mathrm{~nm})$ with a transmission and a backscattering detector. The light that goes through the sample with a $0^{\circ}$ angle [25] is detected at a $45^{\circ}$ angle by the transmission detector [26]. At the same time, the light that goes through the sample with a $135^{\circ}$ angle is recognized at a $180^{\circ}$ angle by the backscattering detector $[25,26]$. The instrument can measure the whole sample, from the top, middle and bottom [27] in $20 \mathrm{~s}$ (1500 points), giving the Backscattering (BS \%) and Transmission ( $\mathrm{T} \%$ ) as results. The dispersion of the particles, which is related to the stability, is measured according to ISO/TR 13097 [28]. BS (\%) and T (\%), are used to identify the phenomena related to the instability of emulsions: creaming, flocculation and sedimentation [27]. The instrument reports the stability with a Turbiscan stability index (TSI), which relates T (\%) and BS (\%) based on the equation:

$T S I(t)=\frac{1}{N_{h}} \sum_{t_{i}=1}^{t^{\max }} \sum_{z_{i}=z_{\min }}^{z_{\max }}\left|B S T\left(t_{i}, z_{i}\right)-B S T\left(t_{i-1}, z_{i}\right)\right|$

where tmax is the point on time $(\mathrm{t})$ that the TSI is measured, $z_{\text {min }}$ and $z_{\max }$ (the lower and high selected limits), $N_{h}=\frac{z_{\max }-z_{\min }}{\Delta \mathrm{h}}$ is the high position in the scan. BST is the signal of BS if T < $0.2 \%$, otherwise is $\mathrm{T}$ [29]. The measurements were performed on a fresh sample. The emulsions were placed in the Turbiscan for 3 days $\left(19{ }^{\circ} \mathrm{C}\right)$ and scanned as follows: every $5 \mathrm{~min}$ for the first $15 \mathrm{~h}$. After this interval, every $30 \mathrm{~min}$ during $9 \mathrm{~h}$ and finally every $1 \mathrm{~h} 30 \mathrm{~min}$ for the last $48 \mathrm{~h}$. The limit of days was set based on the TSI, values higher than 3 indicates that the destabilization process has started, and the changes are relevant in the matrix of the emulsions [29]. 


\section{Hydrodynamic Diameter and Z-Potential Measurements}

The droplet size and charge of the emulsions were determined by Dynamic Light Scattering (DLS) by using Zetasizer NanoZS (Malvern Instruments, Worcestershire, UK) equipped with capillary cells. The samples were diluted 1: 500 with Milli-Q water and analyzed with a scattering angle of $173^{\circ}$ and a wavelength of $633 \mathrm{~nm}$. The $D_{h}$ of particles was calculated by the Stokes-Einstein equation using the diffusion coefficient $\left(D_{t}\right)$ extracted from the fit of the correlation curve using the cumulant method, as follows:

$D_{h}=\frac{K_{B} T}{3 \pi \eta D_{t}}$

where $K_{B}$ is the Boltzmann's constant and $T$, the temperature. The measurements were performed with an applied voltage of $50 \mathrm{~V}$. The $\zeta$-potential was calculated using Henry's equations, as following:

$\zeta=\frac{3 \eta \mu}{2 \varepsilon f\left(\kappa R_{H}\right)}$

where $(\eta)$ is the viscosity of the solvent, $(\mu)$ the electrophoretic mobility, $(\varepsilon)$ the dielectric constant of the medium and [f $\left(\kappa R_{H}\right)$ ], the Henry's function. ( $\left.\mathrm{K}\right)$ is the thickness of the double electric layer or Debye length and $R_{H}$ is the particle radius [30].

\section{Emulsion Droplet Size}

The droplet size of the fresh sample was visualized by the optical microscope Olympus 1 X 51 (Olympus Denmark A/S, Ballerup, Denmark) equipped with an image software (cellSense, Olympus Denmark A/S, Ballerup, Denmark). To capture the images of the different emulsions a $40 \mathrm{x}$ lens with a 0.6 numerical aperture and light source $\mathrm{n}^{\circ} 3$ was adopted. The image analysis of the different emulsions' droplets was performed using Image ${ }^{\circledR}$ software. The image pixels were transformed to $\mu \mathrm{m}$ being 11.76 pixels $/ \mu \mathrm{m}$, then a threshold on the pictures was applied, followed by an analysis of particle size with minimum detection of $1 \mu^{2}$. The results were then treated in Excel ${ }^{\circledR}$ software, obtaining a diameter of the particles in $\mu \mathrm{m}$, used to describe the particle size distribution.

\section{Confocal Laser Scanning Microscopy (CLSM)}

Confocal laser scanning microscopy (CLSM) was employed to determine the presence of the proteins in the interface between the continuous and the dispersed phases of the $\mathrm{O} / \mathrm{W}$ emulsions [31]. The emulsions were dye with Nile red [32] (Sigma-Aldrich Denmark A/S, Søborg, Denmark), dyeing the lipid phase. The dye was excited at $561 \mathrm{~nm}$ by a filter at $607 \mathrm{~nm}$. FCF fast green (Sigma-Aldrich Denmark A/S, Søborg, Denmark) was used to dye the proteins and was excited at $640 \mathrm{~nm}$ by a filter of $700 \mathrm{~nm}$ [33]. A volume of $8 \mu \mathrm{l}$ was deposed on a microscope slide with a coverslip (Marienfeld no $1.5 \mathrm{H}$ ) and sealed the edges with nail polish. Then the sample was imaged using a 100x lens (Nikon CFI plan achromat NA1.45) on a spinning disc confocal microscope constituted by an inverted microscope (Nikon Ti2) equipped with a laser source (405/ 488 / 561 / $640 \mathrm{~nm})$, a confocal spinning disc module (Yokogawa CSU-W1, 50um pinholes), a quad-band emission filter (440/521 / 607 / $700 \mathrm{~nm}$ ) and an sCMOS camera (Photometrics Prime95B).

\section{Thermal Properties by Differential Scanning Calorimetry (DSC)}

The thermal properties of PP and FG were determined by using differential scanning calorimetry (DSC) (Q2000 instrument, TA Instruments Corp., Elstree, Herts, U.K.). A quantity of $5 \mathrm{mg}$ of powder $(11 \% \mathrm{RH})$ was placed into aluminum pans with a hermetic lid and analyzed from $10{ }^{\circ} \mathrm{C}$ to $130{ }^{\circ} \mathrm{C}[32$, 34]. The slurries were prepared by mixing overnight a solution of $30 \% \mathrm{w} / \mathrm{w}$ of proteins in buffer at $\mathrm{pH} 3$. The ratios were 100:0 (A), 75:25 (B), 50:50 (C), 25:75 (D) and 0:100 (E). Then, $30 \mu$ of the slurry was placed into a pan equipped with a hermetic lid and analyzed from $10^{\circ} \mathrm{C}$ to $130^{\circ} \mathrm{C}$. The thermal properties of the emulsions were measured on fresh emulsions by deposing $25 \mu \mathrm{l}$ in a pan equipped with a hermetic lid and analyzed from $10{ }^{\circ} \mathrm{C}$ to $130{ }^{\circ} \mathrm{C}$. Glass transition temperature $(\mathrm{Tg})$, denaturation temperature (Td) and melting temperature (Tm) were determined.

\section{Rheological Analysis}

The flow behavior of emulsions was evaluated with a controlled-stress rheometer (StressTech HR Cannon instruments, State College, PE, US) equipped with a double gap geometry at $19^{\circ} \mathrm{C}$. A volume of $15 \mathrm{ml}$ of sample was deposed and analyzed for steady shear viscosity at a shear rate ranged from $0.1-150 \mathrm{~s}^{-1}$. The Power-law model (Eq. 6) was used to fit the rheological results and the apparent viscosity for Powerlaw fluid obtained using Eq. (7):

$\tau=m \gamma^{\cdot n}$
$\mu_{a}=m \gamma^{\cdot n-1}$

where $\tau$ is the shear stress $(\mathrm{Pa}), \mu_{\mathrm{a}}$ is the apparent viscosity (Pa.s), $m$ is the consistency coefficient $\left(\mathrm{Pa}^{\mathrm{n}} \mathrm{s}^{\mathrm{n}}\right), \dot{\gamma}$ is the shear rate $\left(\mathrm{s}^{-1}\right)$, and $n$ is the flow behavior index. In all the tests a delay of $5 \mathrm{~s}$ was needed for the sample to reduce the noise. Measurements were performed in triplicate. 


\section{Determination of Interfacial Tension and Interfacial Dilatational Properties}

The interfacial properties of the samples, in static and dilatational mode, was determined by the pendant drop technique, using a drop tensiometer OCA 25 (DataPhysics Instruments, Filderstadt, Baden-Württemberg, Germany). The measurements were conducted with $1 \%(w / w)$ of protein in buffer solution at $\mathrm{pH} 3$ stirred overnight. Afterwards, an ultrasound treatment for $10 \mathrm{~min}(10 \mathrm{~s} \mathrm{ON}, 10 \mathrm{~s} \mathrm{OFF})$ at $20 \mathrm{kHz}$ and $550 \mathrm{~W}$ was applied. A drop of $50 \mu \mathrm{l}$ was obtained with a syringe (diameter of $1.62 \mathrm{~mm}$ ). The drop was formed inside a cube of $\left(1 \times 1 \times 1 \mathrm{~cm}^{3}\right)$ filled with $3 \mathrm{ml}$ of fish oil. The changes in interfacial tension were monitored for $15 \mathrm{~min}$.

An oscillatory dilatational test was applied to determine the strength of the droplet under dilatational deformation. The samples were prepared by using the same protocol as described above. Frequency sweep was applied in a frequency range from 0.1 to $1 \mathrm{~Hz}$ and an amplitude of $3 \%$. The test was done in 4 steps $(0.1,0.4,0.7,1 \mathrm{~Hz})$, with $10 \mathrm{~s}$ waiting between each step (step time $10 \mathrm{~s}$ ). The droplet was subjected for four cycles at each frequency. The values of dilatational complex $\left(E^{*}\right)$, storage (E') and loss (E') moduli were obtained.

\section{Statistical Analysis}

The results of particle size, zeta-potential and rheological analysis were submitted to statistical analysis of ttest or ANOVA, pair comparison was achieved by Tukey's test at $p$ value $<0.05$.

\section{Results and Discussion}

\section{Physico-Chemical Characterization}

\section{Chemical Composition}

The physico-chemical properties, as well as the mineral composition of PP and FG, are presented in Table 1. Results showed a significant difference in moisture, ash and protein content between FG and PP. Globally, the moisture content was two orders higher for FG compared to PP, while the ash content for PP was around 4\%, whereas FG had below $1 \%$. Protein content was above $90 \%$ for FG whereas PP presented a value below $80 \%$ (based on the dry basis). Similar protein content for commercial PP was found by Chang, Tu, Gosh and Nickerson [35], with a value close to $78 \%$. In contrast, Liang and Tang [18] obtained a protein content $\sim 93 \%$, by an alkali extraction / acid precipitation process. According to Dickinson [36], a higher protein content induces higher emulsifying properties. Hydrophobicity was increased significantly by ultrasound treatment, with a factor of 1.45 and 2.66 for PP and FG, respectively (Table 1). These results are in agreement with O'Sullivan (2016 and 2017) [5, 37] who reported an increase in the hydrophobicity after ultrasound treatment. The hydrophobicity value of PP before ultrasound treatment found in the present study $(\sim 1680)$ was lower than the values found by Peng et al. [38] ( 2650) and Liang et al. [39] ( 2730) for pea protein. However, the hydrophobicity value of FG, at $\mathrm{pH} 4$ before ultrasound treatment (Table 1), was similar to what has been observed by Liu et al. [40] ( 110). Proteins showing high hydrophobicity values tend to have a higher oil holding capacity, due to more hydrophilic exposed groups [41]. The differences observed in mineral composition between FG and PP can be related to the ash content, as observed in Table 1. In specific, PP had a high content of macro elements, $\mathrm{Na}, \mathrm{Mg}$ and $\mathrm{K}$ compared to FG.

\section{Electrophoretic Study (SDS-PAGE)}

SDS-PAGE of PP and FG is presented in Fig. 1. FG did not present distinct bands corresponding to the main components of collagen, such as the $\alpha$ chains around $120 \mathrm{kDa}$ and $\beta$ chains above $200 \mathrm{kDa}$. This result indicates that extensive hydrolysis of collagen has occurred during the production process of the FG. PP showed distinct proteins bands at the molecular weight (MW) lower than $97 \mathrm{kDa}$ which could come from the globulins vicilin and legumin [32]. The intense bands at around

Table 1 Physico-chemical properties and elemental composition of PP and FG

\begin{tabular}{llll}
\hline & & PP & FG \\
\hline Moisture (\%) & & $0.1 \pm 0$ & $11.4 \pm 0.1$ \\
Ash (\%) & & $3.8 \pm 0$ & $0.2 \pm 0$ \\
Protein (\%) & Untreated & 1679.2 & 100.0 \\
Hydrophobicity & Ultrasound & 2445.8 & 266.8 \\
Macroelements [g/kg dry matter] & $\mathrm{Na}$ & 8.1 & 0.08 \\
& $\mathrm{Mg}$ & 0.7 & 0.01 \\
& $\mathrm{~K}$ & 4.8 & 0.2 \\
& $\mathrm{Ca}$ & $<0.2$ & 0.5 \\
Microelements [mg/kg dry matter] & $\mathrm{Cr}$ & 0.1 & 0.2 \\
& $\mathrm{Mn}$ & 13.6 & 0.01 \\
& $\mathrm{Fe}$ & 174 & 76.4 \\
& $\mathrm{Co}$ & $<0.01$ & $<0.01$ \\
& $\mathrm{Ni}$ & $<0.01$ & 0.06 \\
& $\mathrm{Zn}$ & 88.2 & 0.4 \\
& $\mathrm{Cu}$ & 8.1 & 0.5 \\
& $\mathrm{Se}$ & $<0.01$ & 4.6 \\
& $\mathrm{Sr}$ & 1.3 & 2.2 \\
& $\mathrm{Cd}$ & $<0.01$ & 0.3 \\
& $\mathrm{~Pb}$ & $<0.05$ & $<0.05$ \\
& $\mathrm{Hg}$ & $<0.01$ & $<0.01$ \\
\hline
\end{tabular}




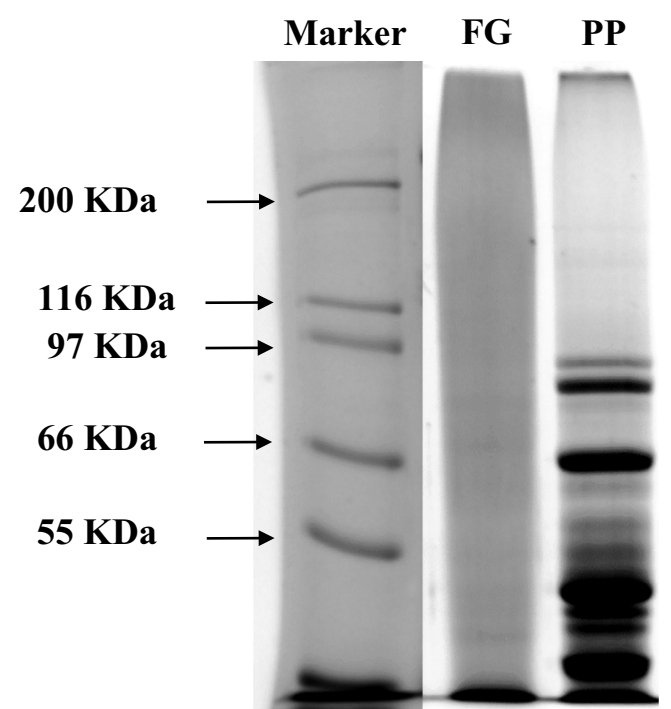

Fig. 1 SDS-PAGE of FG and PP.

$40 \mathrm{kDa}$ and at $20 \mathrm{kDa}$ can be related to legumin subunits [39] that have a higher hydrophobicity than vicilin [41]. According to Dickinson et al. [42], a mix of low and high weight proteins is fundamental for the emulsion system, since lower MW molecules move faster to the interface, increasing the emulsion stability whereas high MW molecules will move slower, but help against coalescence.

\section{Physical Stability of Emulsions}

\section{Turbiscan}

The emulsions stability was measured with the Turbiscan tower and expressed in TSI as a function of time, presented in Fig. 2 image (a). The ratio A has the lowest TSI around 0.26, while ratios $\mathrm{B}, \mathrm{C}$ and $\mathrm{E}$ showed similar values during the first hour, with TSI of 0.51, 0.41 and 0.46, respectively. Further, emulsion D presented the highest value of 1.26. After $6 \mathrm{~h}$ sample D exceeded the TSI value of 3 while emulsion $\mathrm{E}$ and B exceeded 3 after $12 \mathrm{~h}$. In the following period between 12 and $24 \mathrm{~h}$, only the emulsions A and C had a TSI lower than 3 with the respective values of 1.9 and 2.4. Emulsion $\mathrm{C}$ was destabilized after $\sim 35 \mathrm{~h}$, while sample A was stable until $\sim 50 \mathrm{~h}$. It can be concluded that emulsion A, prepared just with FG, showed the highest stability. However, when FG and PP were mixed, the most stable system was represented by an equal ratio of the proteins (50:50). The higher stability might be from a charge and steric stabilization in the interface reach when both proteins were mixed equally [43]. Different results were described by Liang et al. [18]. The authors investigated on $\mathrm{O} / \mathrm{W}$ emulsions stabilized with pea protein of $1 \%$ at $\mathrm{pH} 3$. The system showed low creaming and stability values of 20 days. However, the analysis was performed with visual testing and the initial phases of flocculation and sedimentation were not detectable with the naked eye [25, 26]. LadjalEttoumi, Boudries and Chibane [34] by the analysis of the hydrodynamic diameter obtained stable $\mathrm{O} / \mathrm{W}$ emulsions at pH 3 for 10 days. Benito-Román et al. [44] describe similar results on $\mathrm{O} / \mathrm{W}$ emulsions stabilized with $15 \%$ of $\mathrm{PP}$ and maltodextrin. The authors monitored the stability also with Turbiscan and the system started the flocculation and coalescence phenomena after $24 \mathrm{~h}$. The lower emulsion stability observed in the presence of PP is probably due to their high macro elements content (Table 1). This induces a reduction of the repulsion forces leading towards an unstable system [45]. Further, the higher stability of FG compared to PP might be related to higher protein content and hydrophobic groups, represented in Table 1.

\section{乙-Potential and Hydrodynamic Diameter}

The charge of particles is related to the van der Waals and repulsion forces which affects the stability of emulsions [46]. The $\zeta$-potential values above +30 or lower than $-30 \mathrm{mV}$ are indicative of good stability [47]. The results of the surface charge are presented in Fig. 3a. During the first 2 days, there was no change in the $\zeta$-potential $(\sim 20 \mathrm{mV})$ of sample A. The same tendency was observed for sample E, where the $\zeta$-potential was stable at $\sim 33 \mathrm{mV}$. However, on day 3 , a decrease in $\zeta$-potential of 2 and $8 \mathrm{mV}$ was observed for A and E, respectively. Similar values were founded by Klost \& Drusch [48] for O/W emulsions at $\mathrm{pH}$ 3. They
Fig. 2 TSI value for the sample $-\mathrm{A},-\mathrm{B},-\mathrm{C},-\mathrm{D},-\mathrm{E}$ as a function of time (hours). Image (a) zoom on the first $6 \mathrm{~h}$. Image (b) for the maximum time of stability
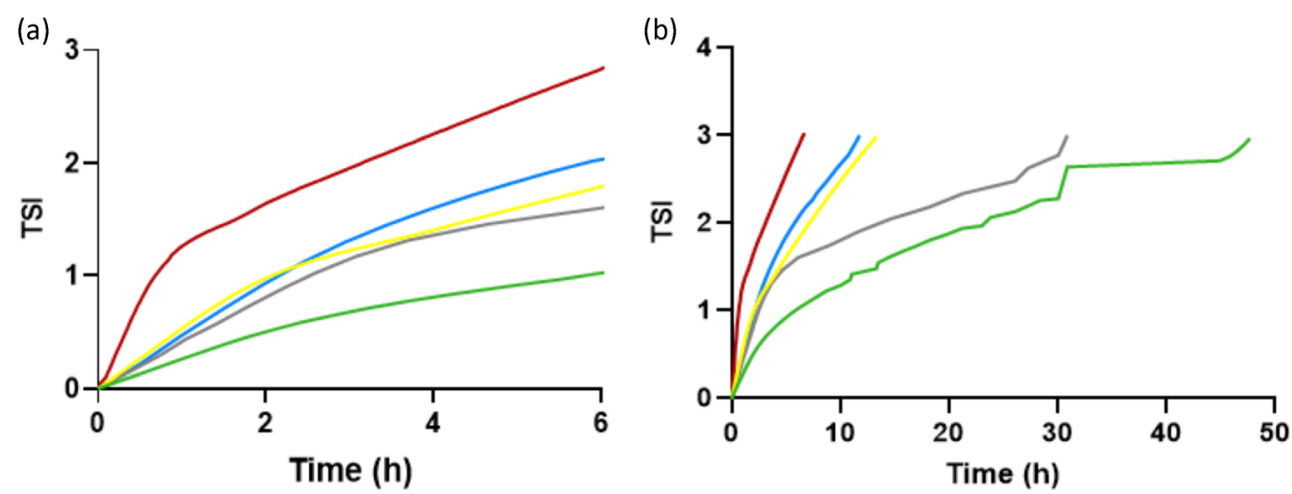
detected a $\zeta$-potential of $30 \mathrm{mV}$ for pea extracted with an alkaline method. In contrast, samples B, C and D presented significant variations during the 3 days. Sample B had $\zeta$ potential values at $\sim 22 \mathrm{mV}$ at day 1 and day 3 . A slight increase was observed at day 2 , where the $\zeta$-potential value increases up to $27 \mathrm{mV}$. Sample $\mathrm{C}$ presented higher stability during the first day, with a value $\sim 34 \mathrm{mV}$. However, a decrease of 2 and $15 \mathrm{mV}$ was observed on day 2 and 3 , respectively. In contrast, emulsion D presented $\zeta$-potential values of 10 to $5 \mathrm{mV}$ on day 1 and 2 , respectively with an increase to $25 \mathrm{mV}$ after $72 \mathrm{~h}$. The increase on the surface charge might be due to the oxidation of the oil as this induces a release of chemical compounds that might cause rearrangement of the interfacial composition leading to chemical changes and/or physical destabilization [49]. The pro-oxidants present in the water phase, surfactant molecules or oxygen incorporated during the emulsion preparation can promote the lipid oxidation $[45,46]$.

The droplet size results are represented in Fig. 3b. Globally, the particle size analyzed did not exceed $3 \mu \mathrm{m}$ in diameter. Sample $\mathrm{A}$ and $\mathrm{C}$ had a stable average hydrodynamic diameter of $0.3 \mu \mathrm{m}$. A slight difference was observed for sample E, which values ranged from 0.39 to $0.56 \mu \mathrm{m}$. Contrary sample B presented a higher droplet size, between 1.8 to $2.6 \mu \mathrm{m}$, whereas the droplet size of sample D ranged from 1.4 to $0.8 \mu \mathrm{m}$. The reduction in droplet size for sample D over time could be attributed to the solubilization of the oil droplets into the water phase and shrinking [50]. These results were correlated with the highest stability showed on Turbiscan by both samples A and C during 30 and 50 h, respectively. Both findings are in agreement with the observations that small size particles tend to form more stable emulsions [41]. Recently, McCarthy, Kennedy, Hogan et al. [51], investigated the stability of $\mathrm{O} / \mathrm{W}$ emulsions stabilized with PP (1\% w/w) obtained by mechanical stirring followed by ultrasonication. The authors applied a fixed frequency of $20 \mathrm{kHz}$ and an amplitude of $100 \%$ (i.e. $266 \mathrm{~W}$ ) at different exposure times: $0.5,1,1.5$ or $2 \mathrm{~min}$. In deionized water, a reduction in size from $4.8 \mu \mathrm{m}$ to $1.1 \mu \mathrm{m}$ was observed when the time increased from 0.5 to
2 min. Their study is in concordance with our results, showing that ultrasound treatment induces a reduction in droplet size.

\section{Optical Analysis}

The morphological characterization of the samples was performed with optical microscopy followed by image analysis using Image $®$ software. The optical microscopy images are presented in Figs. 4a, e, i, m and q. The distribution analysis of the droplets' diameter is presented in Figs. $4 \mathrm{~b}, \mathrm{f}, \mathrm{j}, \mathrm{n}$ and r. Due to limitations of the microscope, only particles $\geq 1 \mu \mathrm{m}$ were visible; all ratios'particle size was between 1 and $4 \mu \mathrm{m}$. The different emulsions had a predominant size between 1 and $2 \mu \mathrm{m}$. Similar results were reported by P.J. García-Moreno, A. Guadix, E.M. Guadix, C. Jacobsen [14], they studied O/W emulsions stabilized with fish protein hydrolysates at $5 \% \mathrm{w} / \mathrm{w}$ from sardine and catshark, with a particles size of 1 and $3 \mu \mathrm{m}$ respectively. The emulsion $\mathrm{E}$, which was constituted only with PP, presented a similar droplet size described by Liang and Tang $[18,19]$.

\section{CLSM Analysis}

CLSM analysis was employed to investigate the presence of the protein at the $\mathrm{O} / \mathrm{W}$ interface. Results are presented in Figs. 4c, g, k, o and s, channel emission at $607 \mathrm{~nm}$, corresponding to orange light, which is the light band of emission for Nile red. Same Figs. 4d, h, 1, p and t, channel emission at $700 \mathrm{~nm}$, corresponding to red light, which is the band of emission for FCF Fast green [33]. For most of the droplets, the signal for both dyes was colocalized. However, CLSM allowed us to image an across section of the larger droplets where the distribution of the two dyes was qualitatively different. Larger droplets from each ratio are visible in the insert on each confocal image in Fig. 4. Surely, the largest droplets (i.e. much larger than the point spread function) appeared as discs in the Nile Red channel, while they appeared as rings in the Fast Green FCF channel indicating that the proteins were accumulated on the $\mathrm{O} / \mathrm{W}$ interface. Moreover, we can observe an
Fig.3 a $\zeta$-potential $(\mathrm{mV})$ measured during 3 days for the sample $-\mathrm{A},-\mathrm{B},-\mathrm{C},-\mathrm{D}$ and - E. b Size $(\mu \mathrm{m})$ measured during 3 days for the sample $-\mathrm{A},-\mathrm{B},-\mathrm{C},-\mathrm{D}$ and $-\mathrm{E}$ (a)

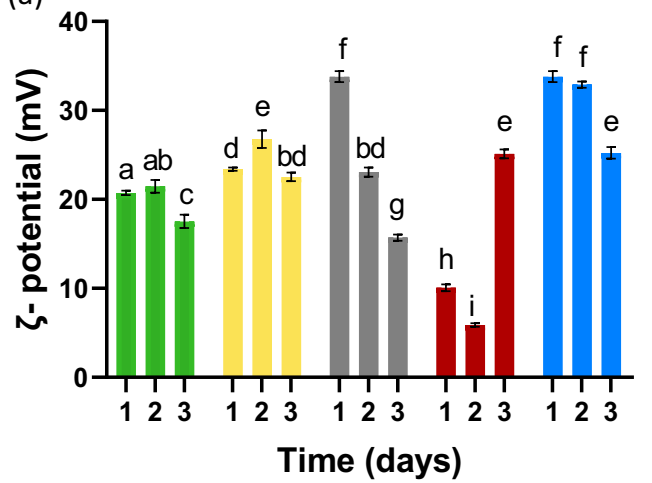

(b)

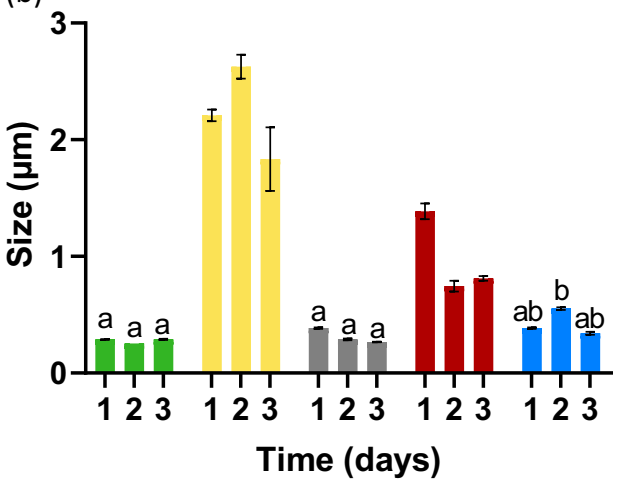


uneven fluorescence distribution of the Fast green FCF suggesting the presence of protein clusters around the oil droplets. Similar images were obtained by Liang and Tang [18], for $\mathrm{O} / \mathrm{W}$ emulsions stabilized with PP proteins. In their study, oil droplets presented a yellow/greenish color, whereas the proteins had a red color. The ring of proteins surrounding the oil droplet was also observed by Zhang, Sun, Ding, Tao, Wang and Zhong [52]. The slight fluorescence of FCF fast green in Fig. 4 image 7, could indicate that this dye has a minimal absorption at 568
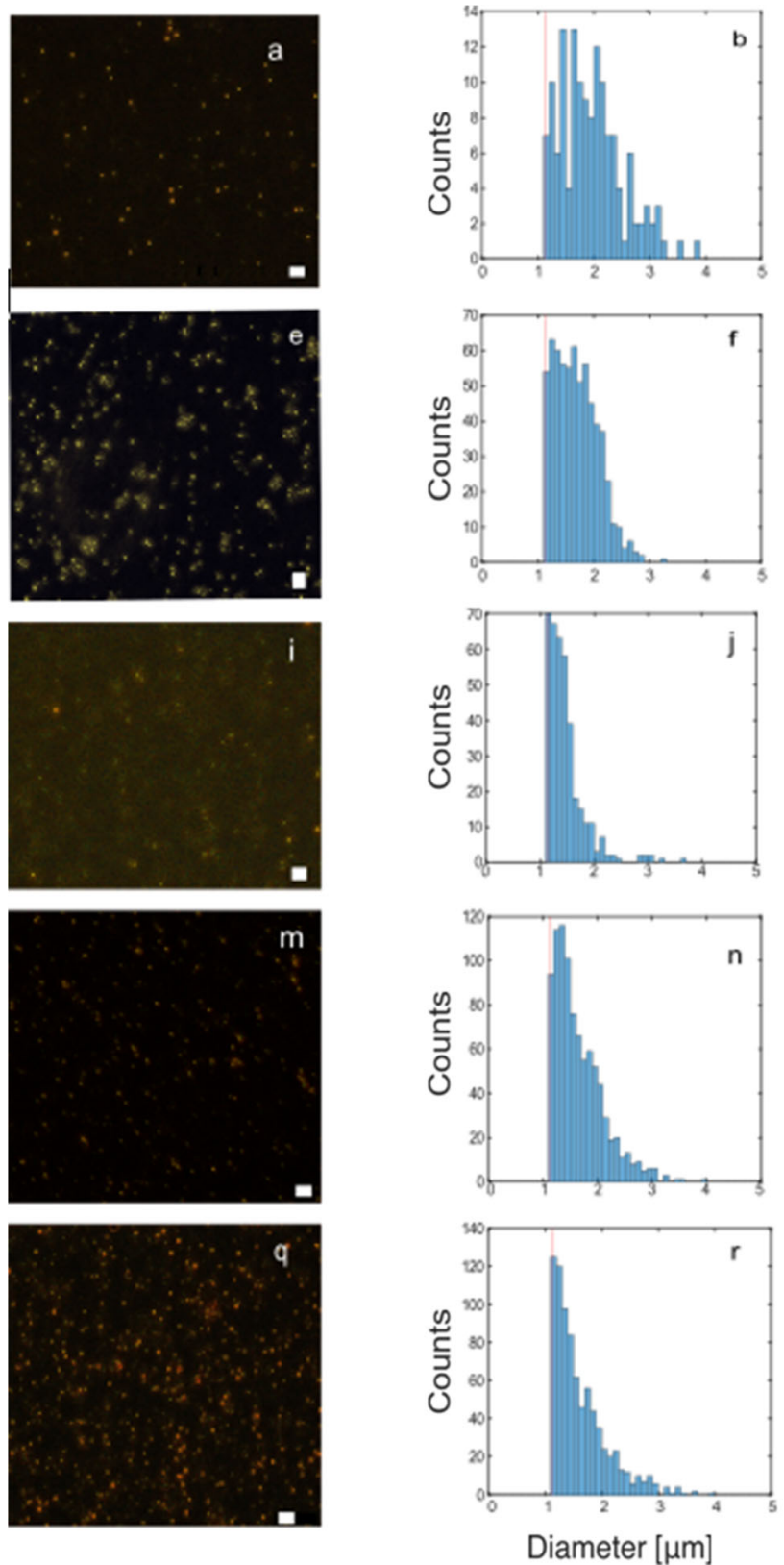

Fig. 4 Microscopy image for the sample A (a) B (e) C (i) D (m) E (q). The size distribution analysis for the sample A (b), B (f), C (j), D (n), E $(\mathbf{r})$, obtained by ImageJ ${ }^{\circledR}$ software analysis. CLSM images realized at emission bands Nile red at $607 \mathrm{~nm} \mathrm{~A} \mathrm{(c),} \mathrm{B} \mathrm{(g),} \mathrm{C} \mathrm{(k),} \mathrm{D} \mathrm{(o),} \mathrm{E} \mathrm{(s)} \mathrm{and}$ wavelength. For all the images ( $d, h, 1, p$ and $t)$, a ring shape can be observed. However, image o, representing sample D, the oil droplets also showed a ring shape. The oil ring presented for this ratio perhaps is because a destabilization phenomenon occurred during the first hour. Endorsed by the results from TSI for this ratio, which were higher than 3 after 6 h. Plus, its low $\zeta$ potential, $10 \mathrm{mV}$, during the first hours after preparation. Besides, as described by Berton-Carabin et al. [53] lipid aggregation can be caused by oil oxidation.
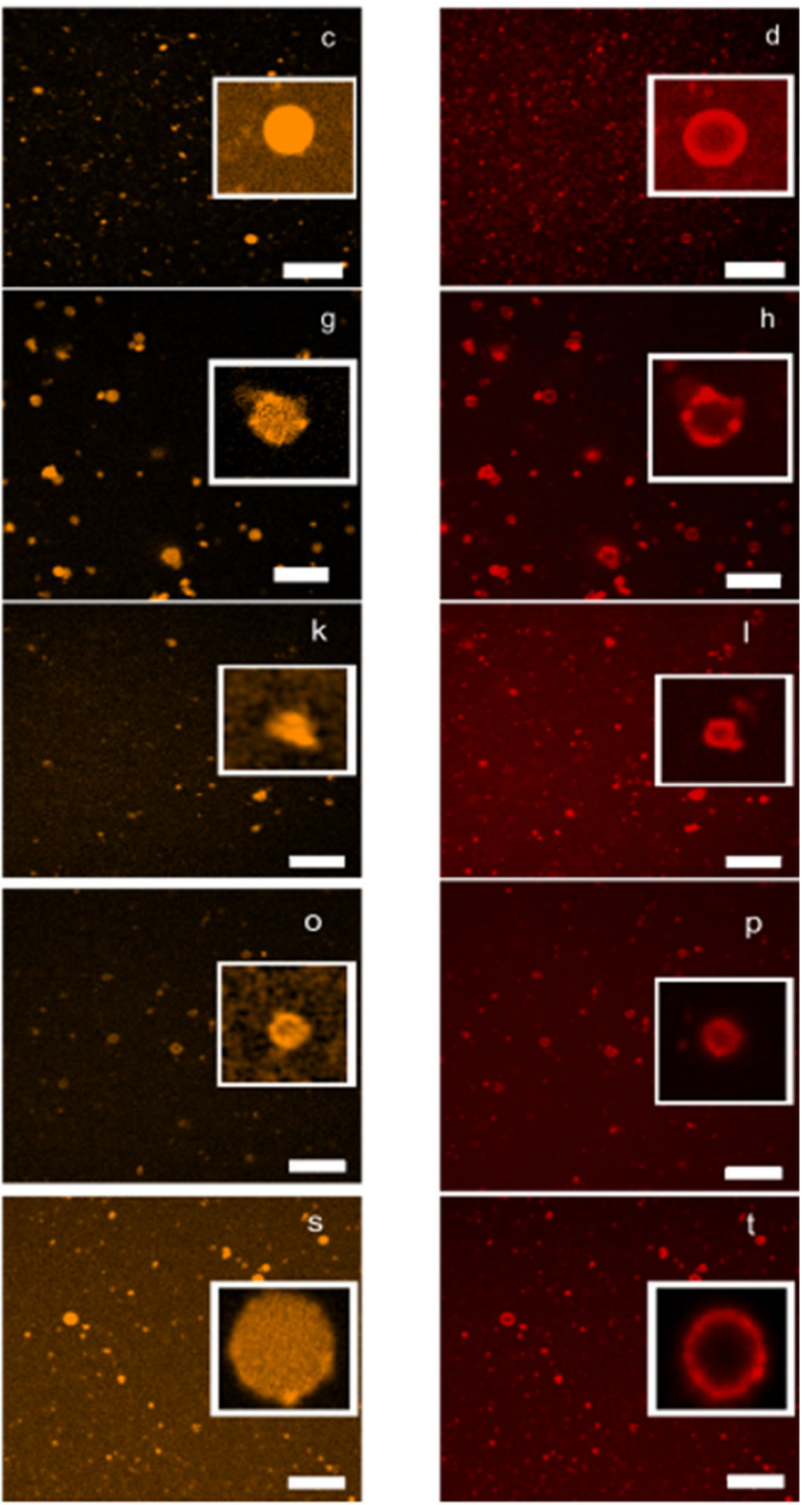

FCF green at $700 \mathrm{~nm} \mathrm{~A} \mathrm{(d),} \mathrm{B} \mathrm{(h),} \mathrm{C} \mathrm{(l),} \mathrm{D} \mathrm{(p),} \mathrm{E} \mathrm{(t),} \mathrm{both} \mathrm{set} \mathrm{of} \mathrm{images}$ present an insert of zoom on a single drop. Scale bar is $10 \mu \mathrm{m}$ for all images 


\section{Thermal Properties by DSC}

The thermal properties of the proteins in powder, slurry and in the $\mathrm{O} / \mathrm{W}$ emulsion interface were characterized using DSC. The results are presented in Table 2 . We reported the glass transition temperature $(\mathrm{Tg})$, denaturation temperature $(\mathrm{Td})$ and melting temperature (Tm). The $\mathrm{Tg}$ indicates a change in the mobility of the molecules [54]. In powder state, FG and PP had a Tg of $73{ }^{\circ} \mathrm{C}$ and $140^{\circ} \mathrm{C}$, respectively, see Table 2, and (Supplementary file 1, Fig. 1). Similar values were observed for fish skin gelatin from yellow tuna, which was found to have a Tg of $60{ }^{\circ} \mathrm{C}$ [55]. Concerning PP, Pelgrom, Schutyser and Boom [56] found a similar $\mathrm{Tg}$ for $\mathrm{PP}$ at $149{ }^{\circ} \mathrm{C}$. The $\mathrm{Td}$ of $\mathrm{FG}$ was detected at $\sim 153{ }^{\circ} \mathrm{C}$. A similar value was reported by Casanova et al. [57], the authors' investigation was on the thermal properties of gelatin from saithe fish skin, found a $\mathrm{Td}$ at $146{ }^{\circ} \mathrm{C}$. Rahman et al. [55] reported a similar $\mathrm{Td}$ of $149{ }^{\circ} \mathrm{C}$ for tuna gelatin. PP exhibited a $\mathrm{Td} \sim 156{ }^{\circ} \mathrm{C}$. A lower $\mathrm{Td}$ value was reported by Liu et al. [58] for PP at $77.3{ }^{\circ} \mathrm{C}$. The differences seen in PP values could be due to different extraction conditions, leading to different thermal properties. Tm values were found at $195{ }^{\circ} \mathrm{C}$ and $175{ }^{\circ} \mathrm{C}$ for $\mathrm{FG}$ and $\mathrm{PP}$, respectively. Tm corresponds to the next transition step, degradation processes [54]. The Tm for $\mathrm{FG}$, in this study, was found $5{ }^{\circ} \mathrm{C}$ higher than the values reported by Casanova et al. [57] where the value was close to $190{ }^{\circ} \mathrm{C}$. The Slurries showed two endothermic peaks, corresponding to the thermal transitions $\mathrm{Td}$ and $\mathrm{Tm}$ (see supplementary file 1, Fig. 2). In this case, the temperatures range from $\sim 60{ }^{\circ} \mathrm{C}$ to $\sim 130{ }^{\circ} \mathrm{C}$. Sample A had a Td of $77{ }^{\circ} \mathrm{C}$ and $\mathrm{Tm}$ of $111.2{ }^{\circ} \mathrm{C}$. Similar results for FG were reported by Zhang et al. [51], where FG showed Td of $72.2^{\circ} \mathrm{C}$ and $\mathrm{Tm}$ of $93.3^{\circ} \mathrm{C}$. Samples B, C and D showed higher Td and Tm than sample A, with temperatures between 84 and $133{ }^{\circ} \mathrm{C}$. Contrary, Sample E had a Td of $62.3{ }^{\circ} \mathrm{C}$ and $\mathrm{Tm}$ of $110.5{ }^{\circ} \mathrm{C}$. Similar values for PP were found by LadjalEttoumi et al. [34] on a slurry system based on $2 \mathrm{mg}$ of PP in $5 \mu$ of deionized water. The authors reported a Td of $83^{\circ} \mathrm{C}$ and $\mathrm{Tm}$ of $104.6^{\circ} \mathrm{C}$. Further, Shand et al. [32], present Td $67^{\circ} \mathrm{C}$ and $\mathrm{Tm} \sim 85^{\circ} \mathrm{C}$ using commercial PP slurry at $10 \%(w /$ w) at $\mathrm{pH}$ 6.5. According to the authors, the first temperature of $\sim 67{ }^{\circ} \mathrm{C}$ was related to the starch from pea protein. In $\mathrm{O} / \mathrm{W}$ emulsion, only a $\mathrm{Td}$ at $97.5^{\circ} \mathrm{C}$ and $108.2^{\circ} \mathrm{C}$ was observed for $\mathrm{A}$ and $\mathrm{B}$. Emulsions $\mathrm{C}, \mathrm{D}$ and $\mathrm{E}$ showed 2 different peaks, corresponding to Td and Tm (see Supplementary File 1, Fig. 2). The $\mathrm{Td}$ values ranged from $\sim 88^{\circ} \mathrm{C}$ to $\sim 100^{\circ} \mathrm{C}$ whereas $\mathrm{Tm}$ was between $\sim 107^{\circ} \mathrm{C}$ and $\sim 112^{\circ} \mathrm{C}$. FG and PP in slurries and $\mathrm{O} / \mathrm{W}$ emulsions showed a lower denaturation temperature compared to their corresponding powder state. This behavior could be related to the interactions with the polar group with water, leading to a change in their structure [59]. Besides,
$\mathrm{O} / \mathrm{W}$ emulsions exhibit a global decrease in Tm compared to the other systems. This might be related to a change in their conformation due to the shear force applied during ultraturrax followed by ultrasound treatment [59].

\section{Flow Behavior of Emulsions}

Figure 5 present the flow behavior of emulsions prepared at different ratios of FG and PP. No significant difference was observed in flow behavior between emulsions B, D and E. However, the shear stress in $\mathrm{A}$ and $\mathrm{C}$ emulsions was noticeably higher than in the other emulsions. To better understand the flow behavior of emulsions, the obtained data were fitted to the Power-law model. The values of consistency coefficient $(m)$ and flow behavior index $(n)$ are reported in Table 3. Based on $n$ value the fluids are categorized in shear-thinning $(n<1)$, Newtonian $(n=1)$ and shear-thickening $(n>1)$ [60]. Over the evaluated range of shear rates, all the emulsions showed Newtonian flow behavior $(n=1)$. The consistency index of emulsions, which represents the apparent viscosity in Newtonian fluids, varied between 0.5 to $2.4 \mathrm{mPa}$.s. The emulsions $\mathrm{A}$ and $\mathrm{C}$ showed a viscosity of 2.4 and $2.0 \mathrm{mPa} . \mathrm{s}$, respectively. These results were similar to the viscosity of fish gelatin of $2 \mathrm{mPa} . \mathrm{s}$ found by Abismail et al. [61]. The emulsions $\mathrm{B}, \mathrm{D}$ and $\mathrm{E}$ showed the lowest viscosity values ranged between 0.5 to $0.7 \mathrm{mPa}$.s. It might be suggested that the flow behavior of emulsion $\mathrm{D}$ was dominated by the contribution of pea protein. These results are in good agreement with those obtained from the physical stability of emulsions Fig. 2. The low stability of emulsions $\mathrm{B}, \mathrm{D}$, and $\mathrm{E}$ could be explained by their low viscosity values.

Table 2 DSC results for powder, slurry solution and $\mathrm{O} / \mathrm{W}$ emulsions. In powder PP and FG are equilibrated at $11 \% \mathrm{RH}$, in slurry solution the different ratios are present at $30 \%(\mathrm{w} / \mathrm{w})$ whereas in $\mathrm{O} / \mathrm{W}$ emulsions a volume of $25 \mu \mathrm{l}$ was employed for A, B, C, D and E system

\begin{tabular}{lllll}
\hline Sample & & $\mathrm{Tg}\left({ }^{\circ} \mathrm{C}\right)$ & $\mathrm{Td}\left({ }^{\circ} \mathrm{C}\right)$ & $\mathrm{Tm}\left({ }^{\circ} \mathrm{C}\right)$ \\
\hline powder & FG & 73.6 & 153.2 & 195.9 \\
\multirow{3}{*}{ slurry } & PP & 140.1 & 156.8 & 175.5 \\
& $\mathrm{~A}$ & & 77.3 & 111.2 \\
& $\mathrm{~B}$ & & 84.0 & 119.6 \\
& $\mathrm{C}$ & & 114.2 & 133.0 \\
& $\mathrm{D}$ & & 95.7 & 128.4 \\
O/W emulsion & $\mathrm{E}$ & & 62.3 & 110.5 \\
& $\mathrm{~A}$ & & 97.5 & - \\
& $\mathrm{B}$ & & 108.2 & - \\
& $\mathrm{C}$ & & 88.4 & 107.5 \\
& $\mathrm{D}$ & & 98.8 & 111.7 \\
& $\mathrm{E}$ & & 100.9 & 110.8 \\
\hline
\end{tabular}




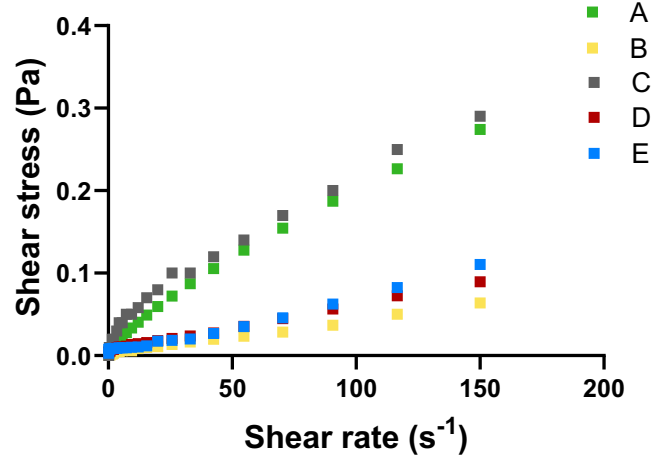

Fig. 5 Shear stress-shear rate profile of emulsions prepared at different ratios of FG-PP. Analysis were performed at $\mathrm{T}=19^{\circ} \mathrm{C}$

\section{Interfacial Behavior}

\section{Static Interfacial Tension}

The interfacial tension was measured with the pendant drop instrument. Fig. 6 presents the interfacial tension as a function of the time for the different ratios of FG and PP. During the first $2 \mathrm{~min}$, the initial interfacial tension of sample A was 17.1 $\mathrm{mNm}^{-1}$, whereas the other samples, B, C, D and E, had a lower value i.e. $13.5,15.0,14.3$ and $14.6 \mathrm{mNm}^{-1}$, respectively. After $5 \mathrm{~min}$, the interfacial tension became stable for the samples $\mathrm{B}, \mathrm{D}, \mathrm{C}$ and $\mathrm{E}$ with values between 13 and $14.3 \mathrm{mN} /$ $\mathrm{m}$. Sample A achieved a stable value of $16 \mathrm{mN} / \mathrm{m}$ after $10 \mathrm{~min}$. Similar results were founded by Gharsallaoui et al. $[42,62]$. The authors, using PP isolates $(\sim 90 \%$ of protein content) in $\mathrm{O} / \mathrm{W}$ emulsion at $\mathrm{pH} 2.4$, found an interfacial tension value close to $13 \mathrm{mN} / \mathrm{m}^{-1}$ after $15 \mathrm{~min}$. This small difference is probably due to the differences in protein content and $\mathrm{pH}$ values. The system containing only PP (E) exhibited lower interfacial tension compared to FG (A). This behavior could be related to the higher hydrophobicity value reported for PP Table 1. Based on, the relationship between lower interfacial tension leads to a higher interfacial activity [63].

Table 3 Power-law model parameters of emulsions prepared at different ratios of $\mathrm{FG}$ and $\mathrm{PP}\left(\mathrm{T}=19^{\circ} \mathrm{C}\right)$

\begin{tabular}{llll}
\hline FG: PP ratio & \multicolumn{2}{l}{ Power-law model } & \\
\cline { 2 - 4 } & $m^{*}\left(\mathrm{mPa}^{\mathrm{n}}{ }^{\mathrm{n}}\right)$ & $n^{* *}$ & $\mathrm{R}^{2}$ \\
\hline A & 2.4 & 1 & 0.97 \\
B & 0.6 & 1 & 0.98 \\
C & 2.0 & 1 & 0.97 \\
D & 0.5 & 1 & 0.98 \\
E & 0.7 & 1 & 0.99 \\
\hline
\end{tabular}

* Consistency coefficient, ** Flow behavior index

\section{Oscillatory Dilatational Rheology}

The study of the interfacial behavior of a droplet in oscillatory information on the elastic properties of the system. In this study, we applied a frequency sweep, from $0.1 \mathrm{~Hz}$ to $1 \mathrm{~Hz}$ and we retrieved the elastic modulus (E') and loss modulus (E"), as presented in Fig. 7. An elastic interface is related to the phenomena of absorption, reorganization and formation of proteins network at the interface [64]. Sample A showed a predominant elastic behavior over the frequencies of 0.1 to $0.7 \mathrm{~Hz}$. Similar behavior was observed by Huang et al. [65] with fish gelatin and egg white proteins at $\mathrm{pH}$ 2.4. The elastic rheological behavior implies a low compressible interface with no relaxation process at the interface [46], which could explain the higher physical stability of emulsion A compared to the rest of the emulsions see Fig. 2. Sample B and C showed an initial elastic behavior at $0.1 \mathrm{~Hz}$, with $\mathrm{E}^{\prime}$ of 7 and $2 \mathrm{mN} / \mathrm{m}$ and E" of 2 and $1 \mathrm{mN} / \mathrm{m}$, respectively. Afterward, the values increased with the frequency with an E" was higher than E', indicating a predominance of the viscous behavior at higher frequencies. A similar tendency was observed for sample D, which had an elastic behavior at frequencies of $0.1-0.4 \mathrm{~Hz}$. However, at higher frequencies, presented a viscous behavior. Sample E showed a viscous behavior at the frequency of $0.1 \mathrm{~Hz}$ and dominant elastic behavior at higher frequencies. This transition from viscous behavior to elastic could be justified because, at higher frequencies, there is not enough time for the proteins in the interfacial network to respond to the dilatational deformations. Thereby the elastic component becomes dominant [66]. Sample E showed a small gap between E' and E" at a frequency of $0.1 \mathrm{~Hz}$. Similar to our results, Amine et al. [67] found a small difference between the values of elastic and viscous modulus for $\mathrm{PP}$ at $1 \%(w / \mathrm{w})$ at $\mathrm{pH} 7$ at a frequency of $0.1 \mathrm{~Hz}$. Contrary, Geerts et al. [68] observed an elastic behavior for yellow pea protein with a $0.1 \%$ concentration at $0.1 \mathrm{~Hz}$. The difference with our results is probably due to the different concentrations of pea protein $(0.1 \%$ vs $1 \%)$. We can observe that the gap between the two

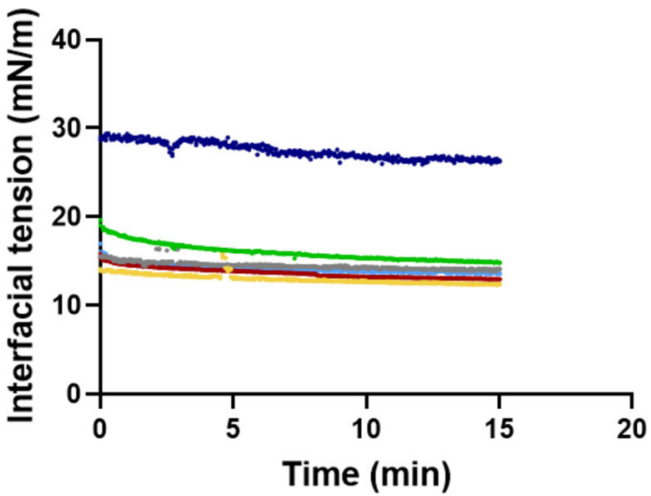

Fig. 6 Interfacial tension of sample - A, - B, - C, - D, - E. Blueline corresponds to water without proteins (water - ) 
components of E' and E" at $0.1 \mathrm{~Hz}$ increases by increment the FG ratio (see Supplementary File 2). This increment might be due to the interaction of proteins in the interfacial region, reinforcing the elastic parameter in the mixed systems [69], which might indicate a possible competition between the two proteins to move into the interface. Fish gelatin has a fibrillar structure which makes it easier to move into the interface compare to the globular structure of pea protein [63]. The observed increasing trend in the viscous modulus of mixed systems (B, C, D) indicates that there was a relaxation of the interface, due to an exchange of molecules between the bulk and the interface [66]. It might further reflect that some level of protein-protein interactions occurred in the interface of mixed systems, which led to the formation of a more compressible interface with no resistance to deformation [46] compared to those from samples $\mathrm{A}$ and $\mathrm{E}$.

\section{Conclusion}

$\mathrm{O} / \mathrm{W}$ emulsions were prepared at different ratios of $\mathrm{FG}$ and PP. Globally, all the systems presented low viscosity and
Newtonian behavior with similar thermal properties. CLSM results indicate that for all the ratios, the proteins were in the oil in water interface. The highest physical stability was observed for ratio $\mathrm{A}$ (100: 0$)$, of $50 \mathrm{~h}$, followed by ratio $\mathrm{C}$ (50: 50 ) of $30 \mathrm{~h}$. Further, the $\mathrm{O} / \mathrm{W}$ emulsion prepared equally with both proteins (50: 50$)$ presented the smallest sizes $(0.3 \mu \mathrm{m})$ between the ratios containing oth proteins, and an average $\zeta$ potential of $\sim 20 \mathrm{mV}$. The equal mixing of FG and PP seems to increase the stability of the emulsions and decrease the particle size of the o/w emulsions, while the inequivalent mix $(75: 25)$ and $(25: 75)$ showed the contrary, a decrease instability and an increase on the particle size compared to the single PP emulsions. The presence of both proteins in an emulsion led to a lower interfacial tension compared to FG alone. The interface at low frequencies was elastic and at higher frequencies was viscous, due to possible movement of proteins from the bulk to the interface. Further investigations will be necessary to understand the displacement of the proteins from the bulk and their relative re-arranging at the oil-water interface. Besides, to increase the physical stability of the systems, it will be interesting to explore further the effect of different protein concentrations. In conclusion, the mixing of proteins
Fig. 7 Interfacial viscoelastic properties for samples A, B, C, D and $\mathrm{E}$ at frequencies of $0.1,0.4$, 0.7 and $1 \mathrm{~Hz}$. For all the graphs, elastic modulus (E') is represented with dot line and $\mathbf{m}$, viscous modulus (E") is represented with a dotted line and $\square$ (a)

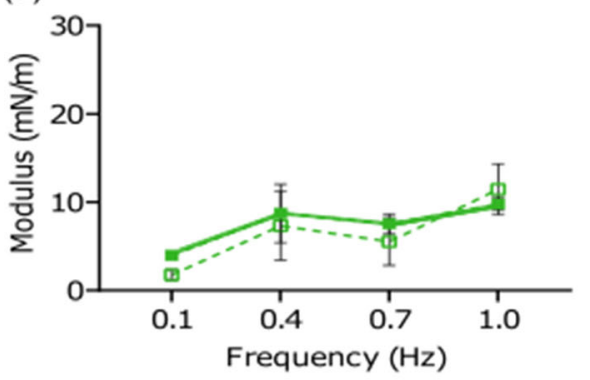

(c)

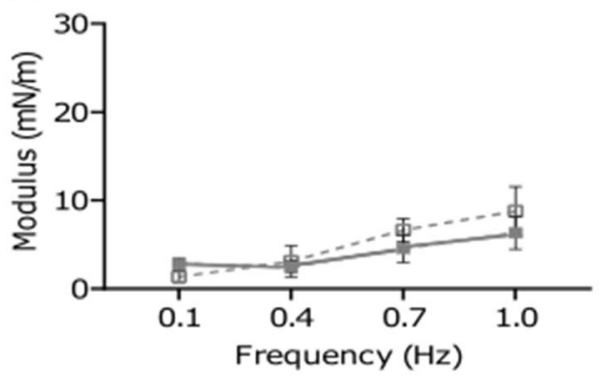

(b)

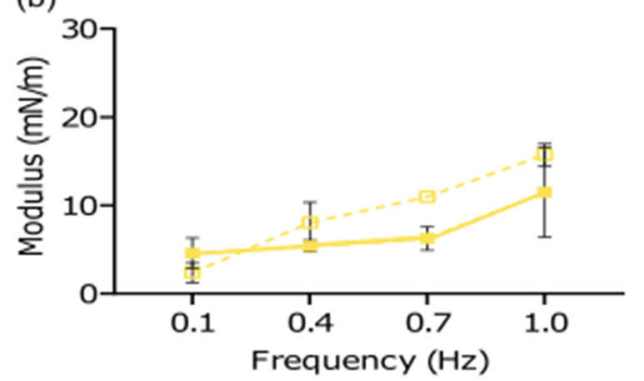

(d)

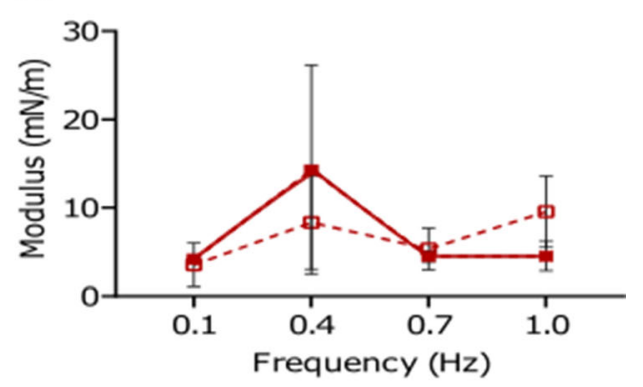

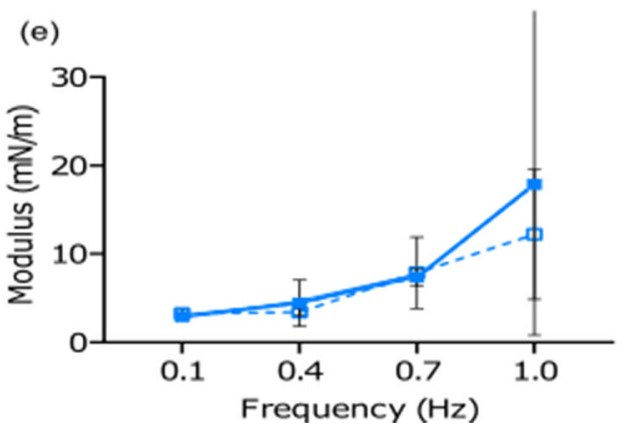


from marine sources and plant-based proteins opens perspectives on new product development for the food industry.

Acknowledgments The authors acknowledge Lipromar GmbH to provide the fish oil. The authors acknowledge the support provided by the Green Development and Demonstration Program (GUDP) and Ministry of Environment and Food of Denmark (J.Nr. 34009-17-1299).

Authors' Contributions Mar Vall-llosera: Term, Conceptualization, validation, formal analysis, investigation, resources, writing, writing review, visualisation. Flemming Jessen: Resources, writing review. Pauline Henriet: Conceptualization, resources, writing review. Rodolphe Marie: Resources, writing review. Mastaneh Jahromi: Resources, writing review. Jens J. Sloth: Resources, writing review. Mohammad Amin Mohammadifar: Resources, writing review. Heidi Olander Petersen: Resources, writing review. Bo Munk Jørgensen: Formal analysis, resources. Federico Casanova: Term, conceptualization, resources, writing, writing review, supervision.

\section{References}

1. R.S.H. Lam, M.T. Nickerson, Food Chem. 141(2), 975-984 (2013)

2. C.C. Loi, G.T. Eyres, E.J. Birch, In Encycl. Food Chem. (Elsevier, 2018), pp. 404-409 (2018)

3. D. J. McClements, Food Emulsions - Principles, Practices and Techniques, 3rd Ed., 3rd editio (Boca Raton, 2016)

4. L. De Souza, G. Leite, B. Tonole, G. Batalha, D. Souza, Ultrason. Sonochemistry 59, 104754 (2019)

5. J.J. O'Sullivan, M. Park, J. Beevers, R.W. Greenwood, I.T. Norton, Food Hydrocoll. 71, 299-310 (2017)

6. M.A. Bos, T. Van Vliet, Adv. Colloid Interf. Sci. 91(3), 437-471 (2001)

7. M. Félix, C. Carrera, A. Romero, C. Bengoechea, A. Guerrero, Food Hydrocoll. 104, (2020)

8. E. Chen, S. Wu, D.J. McClements, B. Li, Y. Li, Food Hydrocoll. 69, 103-110 (2017)

9. F. Lazzaro, A. Saint-Jalmes, F. Violleau, C. Lopez, M. GaucherDelmas, M.N. Madec, E. Beaucher, F. Gaucheron, Food Hydrocoll. 63, 189-200 (2017)

10. C. Wang, Z. Liu, G. Xu, B. Yin, P. Yao, Food Hydrocoll. 61, 11-19 (2016)

11. A.A. Karim, R. Bhat, Food Hydrocoll. 23(3), 563-576 (2009)

12. M. Ding, T. Zhang, H. Zhang, N. Tao, X. Wang, J. Zhong, Food Sci. Hum. Wellness (2020)

13. J. Surh, E.A. Decker, D.J. McClements, Food Hydrocoll. 20(5), 596-606 (2006)

14. P.J. García-Moreno, A. Guadix, E.M. Guadix, C. Jacobsen, Food Chem. 203, 124-135 (2016)

15. Y. Liang, S.S. Wong, S.Q. Pham, J.J. Tan, Food Hydrocoll. 54, 8998 (2016)

16. E.B.A. Hinderink, K. Münch, L. Sagis, K. Schroën, C.C. BertonCarabin, Food Hydrocoll. 97, 105206 (2019)

17. R.E. Aluko, O.A. Mofolasayo, B.M. Watts, J. Agric. Food Chem. 57(20), 9793-9800 (2009)

18. H.N. Liang, C.H. Tang, LWT. Food Sci. Technol. 58, 463 (2014)

19. M. Barac, S. Cabrilo, M. Pesic, S. Stanojevic, S. Zilic, O. Macej, N. Ristic, Int. J. Mol. Sci. 11(12), 4973-4990 (2010)

20. J. Dr. William Horwitz, Editor Dr. George W. Latimer, Book: Official Methods of Analysis (AOAC) (Gaithersburg.Md, 2005)

21. H. N. Liang and C. H. Tang, Food Hydrocoll. 33, (2013)

22. U.K. Laemmli, Nature 227(5259), 680-685 (1970)
23. T. Rabilloud and S. Charmont, In Proteome Res. Two-Dimensional Gel Electrophor. Identif. Methods, edited by T. Rabilloud (Springer Berlin Heidelberg, Berlin, Heidelberg, 2000), pp. 107-126 (2000)

24. B. Nazari, M.A. Mohammadifar, S. Shojaee-Aliabadi, E. Feizollahi, L. Mirmoghtadaie, Ultrason. Sonochem. 41, 382-388 (2018)

25. Z. Liu, Y. Xue, Z. Qiang, Adv. Mater. Res. 936, 1592-1596 (2014)

26. K. Wang, G. Li, B. Zhang, Colloids Surf. A Physicochem. Eng. Asp. 558, 402-409 (2018)

27. L. M. Herrera, Analytical Techniques for Studying the Physical Properties of Lipid Emulsions (Springer New York LLC, 2012)

28. Formulaction, (n.d.)

29. Formulaction, (2020)

30. F. Casanova, N. F. Nogueira Silva, F. Gaucheron, M. H. Nogueira, A. V. N. C. Teixeira, I. T. Perrone, M. P. Alves, P. C. Fidelis, and A. F. d Carvalho, Int. Dairy J. 68, 70 (2017)

31. J. Jiang, B. Zhu, Y. Liu, Y.L. Xiong, J. Agric. Food Chem. 62(7), 1683-1691 (2014)

32. P. J. Shand, H. Ya, Z. Pietrasik, and P. K. J. P. D. Wanasundara, Food Chem. 102, 1119 (2007)

33. K. Manoi, S.S.H. Rizvi, Food Hydrocoll. 23(7), 1837-1847 (2009)

34. Y. Ladjal-Ettoumi, H. Boudries, M. Chibane, A. Romero, Food Biophys. 11(1), 43-51 (2016)

35. C. Chang, S. Tu, S. Ghosh, M.T. Nickerson, Food Res. Int. 77, 360-367 (2015)

36. E. Dickinson, B.S. Murray, G. Stainsby, D.M.W. Anderson, Top. Catal. 2, 477 (1988)

37. J. O'Sullivan, B. Murray, C. Flynn, I. Norton, Food Hydrocoll. 53, 141-154 (2016)

38. W. Peng, X. Kong, Y. Chen, C. Zhang, Y. Yang, Y. Hua, Food Hydrocoll. 52, 301-310 (2016)

39. H.N. Liang, C.H. Tang, Food Hydrocoll. 33(2), 309-319 (2013)

40. H. Liu, B. Wang, C.J. Barrow, B. Adhikari, Food Chem. 143, 484 491 (2014)

41. A.C.Y. Lam, A. Can Karaca, R.T. Tyler, M.T. Nickerson, Food Rev. Int. 34(2), 126-147 (2018)

42. E. Dickinson, V.B. Galazka, D.M.W. Anderson, Carbohydr. Polym. 14(4), 385-392 (1991)

43. E. Dickinson, In Food Hydrocoll. Struct. Prop. Funct., edited by K. Nishinari and E. Doi (Springer US, Boston, MA), pp. 387-398 (1993)

44. Benito-Román, T. Sanz, and S. Beltrán, Heliyon 6, (2020)

45. Y. Liang, L. Matia-Merino, G. Gillies, H. Patel, A. Ye, M. Golding, Curr. Opin. Colloid Interface Sci. 28, 63-73 (2017)

46. A. Gharsallaoui, K. Yamauchi, O. Chambin, E. Cases, R. Saurel, Carbohydr. Polym. 80(3), 817-827 (2010)

47. A. Kumar, C. K. Dixit, In Adv. Nanomedicine Deliv. Ther. Nucleic Acids (Elsevier Inc.), pp. 44-58 (2017)

48. M. Klost, S. Drusch, Food Hydrocoll. 86, 134-140 (2019)

49. S. Tamnak, H. Mirhosseini, C.P. Tan, H.M. Ghazali, K. Muhammad, Food Hydrocoll. 56, 405-416 (2016)

50. R. Santipanichwong, M. Suphantharika, Food Hydrocoll. 21(4), 565-574 (2007)

51. N.A. McCarthy, D. Kennedy, S.A. Hogan, P.M. Kelly, K. Thapa, K.M. Murphy, M.A. Fenelon, Food Res. Int. 89(Pt 1), 415-421 (2016)

52. T. Zhang, R. Sun, M. Ding, L. Li, N. Tao, X. Wang, J. Zhong, LWT 125, 109207 (2020)

53. C.C. Berton-Carabin, M.-H. Ropers, C. Genot, Compr. Rev. Food Sci. Food Saf. 13(5), 945-977 (2014)

54. C. Leyva-Porras, P. Cruz-Alcantar, V. Espinosa-Solís, E. MartínezGuerra, C. I. Piñón-Balderrama, I. Compean Martínez, and M. Z. Saavedra-Leos, Polymers (Basel). 12, 5 (2019)

55. M.S. Rahman, G.S. Al-Saidi, N. Guizani, Food Chem. 108(2), 472-481 (2008) 
56. P.J.M. Pelgrom, M.A.I. Schutyser, R.M. Boom, Food Bioprocess Technol. 6(12), 3317-3325 (2013)

57. F. Casanova, M.A. Mohammadifar, M. Jahromi, H.O. Petersen, J.J. Sloth, K.L. Eybye, S. Kobbelgaard, G. Jakobsen, F. Jessen, Int. J. Biol. Macromol. 156, 918-927 (2020)

58. Y. Liu, D. Wang, J. Wang, Y. Yang, L. Zhang, J. Li, S. Wang, Int. J. Food Sci. Technol. 55(5), 2002-2010 (2020)

59. L. Jorgensen, M. Van De Weert, C. Vermehren, S. Bjerregaard, S. Frokjaer, J. Pharm. Sci. 93(7), 1847-1859 (2004)

60. Q. Zhao, Z. Long, J. Kong, T. Liu, D. Sun-Waterhouse, M. Zhao, Food Hydrocoll. 43, 137-145 (2015)

61. B. Abismaïl, J.P. Canselier, A.M. Wilhelm, H. Delmas, C. Gourdon, Ultrason. Sonochem. 6(1-2), 75-83 (1999)

62. A. Gharsallaoui, E. Cases, O. Chambin, R. Saurel, Food Biophys. 4(4), 273-280 (2009)

63. G. Lu, H. Chen, J. Li, Colloids Surf. A Physicochem. Eng. Asp. 215(1-3), 25-32 (2003)

64. J. Xiao, Y. Li, Q. Huang, Trends Food Sci. Technol. 55, 48-60 (2016)
65. T. Huang, Z. Tu, H. Wang, X. Shangguan, L. Zhang, P. Niu, X. Sha, Colloids Surf. A Physicochem. Eng. Asp. 512, 171-177 (2017)

66. H. Zhang, G. Xu, T. Liu, L. Xu, Y. Zhou, Colloids Surf. A Physicochem. Eng. Asp. 416, 23-31 (2013)

67. C. Amine, J. Dreher, T. Helgason, T. Tadros, Food Hydrocoll. 39, 180-186 (2014)

68. M.E.J. Geerts, C.V. Nikiforidis, A.J. van der Goot, A. van der Padt, Food Struct. 14, 104-111 (2017)

69. J.N. Miquelim, S.C.S. Lannes, R. Mezzenga, Food Hydrocoll. 24(4), 398-405 (2010)

70. T. Varzarkas, V. Polychniatou, and C. Tzia, In Food Eng. Handbook. Food Process Eng., edited by T. Varzakas and C. Tzia, 1st editio (Boca Raton: CRC Press), pp. 231-232 (2015)

71. X.D. Sun, S.D. Arntfield, Food Chem. 124(3), 1011-1016 (2011)

Publisher's Note Springer Nature remains neutral with regard to jurisdictional claims in published maps and institutional affiliations. 